\title{
OGNEN VANGELDV* \\ Stalled European Integration, the Primordialization of Nationalism, and Autocratization in Macedania between 2008 and 2015
}

*[ognen.vangelov@queensu.ca] (Queen’s University, Canada)

\begin{abstract}
In recent years, a kind of democratic failure appeared in the previously successfully democratized region of post-communist Europe. Problems of democratic deficit, and the deterioration of democracy have been increasingly observed in countries that had earlier been considered 'success stories' of democratization. One such case is Macedonia, a country that managed to separate peacefully from Yugoslavia amidst bloody civil wars in the neighborhood and managed to democratize and sustain democracy. Although Macedonia exhibited problems of ethno-national contestations during the period of transition, its democratic development continued in spite of the brief inter-ethnic conflict in 2001. If this success story had continued as predicted, it could be cited as a positive example of how democracy can be consolidated despite ethno-national contestations. However, from 2008 Macedonia began regressing democratically, gradually slipping into competitive authoritarianism. This article examines the process of autocratization in Macedonia through an analysis of how an exogenous shock enabled internal formative events in that the ruling regime headed by Prime Minister Nikola Gruevski commenced a process of primordialization of nationalism. This in turn produced a severe intra-Macedonian cleavage, along with further strains in Macedonia's inter-ethnic relations, giving an opportunity to the ruling party with its chief Nikola Gruevski to capture state institutions and consolidate a competitive authoritarian regime.
\end{abstract}

Keywords: Autocratization; Exogenous Shock; Formative Events; Primordialization; Nationalism; Competitive Authoritarianism. 


\section{Introduction}

In recent years, a significant deterioration of democratic government has been observed in a number of countries in post-communist Europe, where earlier developments created widespread expectations for increased democratic consolidation. Reports about regress in democratic standards have emerged from various parts of this region, including new EU member states - most prominently Hungary (Czigler, 2012; Gyarfasova, 2013; Müller, 2014). Regress to authoritarian policies has also been observed in successor states of the former Yugoslavia that had established democratic institutions and aspired to EU membership - most visibly in Macedonia (Żornaczuk, 2014; Abazi, 2014). These developments signal a regional pattern of autocratization that challenges earlier expectations about democratic consolidation in this region. Much of the literature on democratization in postcommunist Europe has identified the European Union as an imperfect, yet still significant facilitator of democratic development in countries aspiring to membership and those that become EU members (Levitsky and Way, 2005; 2010). The failure of countries to progress toward democratic consolidation has been in the focus of scholarship on Russia and former Soviet states that remained significantly tied to Russian political development. Thus, important questions remain unexplained: are countries that were considered 'success stories' of democratization for a significant period shifting to authoritarianism? If so, what are the sources of such a shift?

Existing literature on democratic regress and the breakdown of democratic regimes has identified several contributing factors, most notably elite fracturing and polarization (Stepan and Linz, 1978; Simon, 1978; Bermeo, 2003), economic factors (Svolik, 2008), and institutional opportunities (Crenson and Ginsberg, 2002). The aim of this article is to explore the way nationalism features in the process of autocratization, through a case study of Macedonia's gradual slippage into competitive authoritarianism, brought about by the right wing ruling elites in Macedonia that have ruled the country since 2006. The process of autocratization that has crystallized in Macedonia also seems to become palpable in other previously democratized countries in the region of Central and Eastern Europe, such as Hungary, and more recently Serbia and Poland (Somun, 2014; Strzelecki and Skolimovski, 2016). Macedonia emerged as an independent state from the violent collapse of Yugoslavia with a democratic government (Daskalovski, 1999). Even though it was considered an unlikely democratizer (it suffered an inter-ethnic violent conflict in 2001, and has had continuous identity disputes with some of its neighbours), Macedonia underwent significant democratization (Levitsky and Way, 2010). Against this precarious backdrop, Macedonia was considered a Balkan success story in democratization; it became a European Union candidate for full membership in 2005, and was on its way to join NATO in 2008. Yet, after its stalled NATO and EU accessions in 2008 due to Greece's objections, Macedonia has seen a gradual but steady democratic regress which transformed its democracy into a political system that resembles what Levitsky and Way (2010) call competitive authoritarianism. The central feature of competitive authoritarianism is the lack of a reasonably level playing field between the incumbents and the opposition, thus the competitive component of the electoral process is severely compromised. I find this concept to be useful for capturing the significance of 
autocratization in Macedonia. The analysis in this paper, inter alia, demonstrates how the level playing field between the incumbents and the opposition has been systematically and profoundly disrupted, and how nationalism became a significant framing instrument in this process.

I argue that Macedonia's autocratization, or slippage into competitive authoritarianism, has been triggered by the indefinite stalling of Macedonia's EuroAtlantic accession caused by the Greek veto in 2008. The Greek veto became the enabling factor for Prime Minister Nikola Gruevski and his government to commence a zealous process of what has been known as 'antiquization', ${ }^{1}$ and what I call the primordialization of Macedonian nationalism, a form of nativism grounded in the idea of ancient rootedness. Primordialization unfolded through government programmes and strategies that together formed a comprehensive campaign designed to appeal to ethnic Macedonians as heirs of Alexander the Great's kingdom. Although the process has been largely referred to as 'antiquization' and sometimes compared to fabrication of national myths of origin and a glorious past elsewhere in nationalist, elite-driven nationalizing policies, I find that the term 'primordialization of nationalism' better captures this process in Macedonia since it signifies the (re)construction of the Macedonian ethno-national identification with myths and narratives that stretch further back to antiquity, in parallel to already existing national myths, with the purpose to infuse a new sense of ethno-national self-identification among ethnic Macedonians. Political elites justified this campaign as an effort to defend the country's name from Greek demands for its re-naming; but in the process Macedonia became re-conceptualized internally as a state that belonged primarily to members of a Macedonian ethno-nation, with roots in antiquity. The discourse and policies associated with this new identity (paradoxically branded as ancient) seems to have had a strong echo in a part of the Macedonian populace, while opponents were labelled as traitors and enemies of the nation. This strategy engendered a deep political and identitarian cleavage among ethnic Macedonians, while further straining inter-ethnic Macedonian-Albanian relations.

The Greek veto of 2008 at the same time significantly limited the EU's leverage in Macedonia in terms of accession standards conditionality. Since Macedonia was already a candidate to become a full member of the EU since 2005, the veto on the beginning of accession talks has largely prevented EU institutions from overseeing the democratic practices and processes in Macedonia through the accession negotiations in a more direct manner, and thus to quell the autocratization tendencies of Gruevski's government at the onset of this process.

In this process, nationalism was both cause and effect, demonstrating the recursive quality of human action (Beissinger, 2002: 9). In the first phase of this process, nationalist contestations in Macedonia came to surface with the dissolution of

\footnotetext{
1 'Antiquization is a term coined by architectural historians to refer to the Renaissance practice of giving a city the appearance of ancient Rome or Athens through the introductions of structures organized in the classical mode. These were occasionally temporary, as in the case of the 'cérémonies à l'antique' - public events of a political content - but more frequently permanent. This phenomenon became visible in Rome and Florence and in the other major Italian towns around the fifteenth century and spread through the cities of the north - Lyon, Paris, Antwerp and London - throughout all the world, up to our times.' (Tzonis Alexander and Liane Lefaivre, 1986, as cited in Vangeli, 2009: 24).
} 
Yugoslavia and the creation of the independent Macedonian state. The source of nationalism at that time had been the debate about whether Macedonia should be a 'nation state' of the ethnic Macedonian people, or a state shared with its ethnonational minorities, particularly the Albanian minority, which at the time made up 23 per cent of the population. The debate was amplified by immediate external challenges to Macedonian existence as a nation, with control over its own national attributes, such as name and language, from Greece, and to some extent also Bulgaria. These challenges instilled fear and uncertainty among ethnic Macedonians. Nonetheless, during this period Macedonian ethnic nationalism did not become a dominant feature in Macedonian politics. The political elites at the time were intent on creating a liberal/civic constitution and compromised on important demands made by ethnic minorities. The moderation of Macedonian ethnic nationalism during that period was reinforced by fear from a possible spill-over of the horrifying 'ethnic conflict' war in Croatia, Bosnia-Herzegovina, and later Kosovo. Another major incentive for moderation was the overwhelming political consensus in the country on the goal of joining the post-communist democratizing countries lined up for EU membership.

However, the nature of Macedonian ethnic nationalism changed significantly after the violent Macedonian-Albanian conflict in 2001, and acquired the crucial boost after the Greek veto for Macedonia's Euro-Atlantic integration. In this period, Macedonian ethnic nationalism shifted from a majoritarian nationalism, which was primarily concerned with inter-ethnic Macedonian-Albanian relations, into an identitarian nationalism defined by policies of primordialization, as manufactured by the right-wing ruler, Nikola Gruevski, and his party Internal Macedonian Revolutionary Organization - Party for Macedonian National Unity (VMRO DPMNE). This nationalism focused on the homogenization of a Macedonian ethnic nation, the survival and well-being of which needs to be actively defended from both internal (Albanian) and external (Greek and Bulgarian) threats. This nationalist project engendered a deep intra-ethnic identitarian cleavage, in which the electorates were turned into camps divided, inter alia, over issues of identity. The camp supporting Prime Minister Nikola Gruevski became the one associated with this new, primordialized (ancient rooted) identity, whereas the camp opposing it (the SocialDemocratic led opposition) was branded enemies of the nation as it was resolutely against such identitarian engineering. The transformed nationalism instrumentalized by Nikola Gruevski could only be successfully propelled after the Greek veto in 2008 . These developments, though initially viewed as temporary reactions to outside pressures, led to a steady deterioration of democracy, ultimately resulting in the consolidation of a competitive authoritarian regime.

In other words, the transformed nationalist narrative enabled ruling elites to capture state institutions, fuse them with the ruling party and embark on a steady installation of an authoritarian regime in the country. As Brubaker (1996) contends, exogenous shocks can trigger formative events within the country, such as the process of primordialization of nationalism. The exogenous shocks together with the domestic formative events then put a strain on fledgling democratic institutions. On the one hand, the boundary between majority and minority social and political fields solidified, and on the other hand, a deep intra-Macedonian political and identitarian 
cleavage was created. This process weakened the ability of social actors to build crossethnic resistance and intra-ethnic cooperation and the preservation of the social contract, which would be necessary to counter the regime's authoritarian policies. The weakness of cross-ethnic and intra-ethnic social resistance enabled political elites to take control of (formerly) democratic institutions.

After defining the concept of autocratization and explaining its usefulness in the post-communist context, I will analyze and demonstrate how the inter-ethnic (Macedonian-Albanian) conflict of $2001^{2}$ triggered the growth and mobilization of Macedonian ethnic nationalism. Then, I will discuss post-violence attempts to achieve democratic consolidation, illustrating how the hardening of ethno-nationalist boundaries and the newly created intra-Macedonian identitarian cleavage triggered and fueled by the Greek veto to Macedonia's Euro-Atlantic integration attempts contributed to the failure of those efforts and to the rise of competitive authoritarianism. I will conclude the discussion with implications for democratic theory building and avenues for future research.

\section{Defining Autocratization}

In general terms, autocratization can occur in any democratized country, with various levels of democratic consolidation. Failed democratization, on the other hand, can occur when an authoritarian country experiences a regime change through multiparty elections, but subsequent governments fail to build and consolidate democratic institutions, and in some cases strengthen and consolidate authoritarianism. In other words, countries with failed democratizations have never reached the point of consolidating their democratic institutions. Although sometimes the line between the two types of transition can be unclear, it is important to analytically define it as this distinction can help us in properly tracing the processes of democratic progress and regress, especially in more recently democratized societies.

An influential category for classifying the countries that failed to reach democratic consolidation is 'hybrid regime', which suggests that a country is neither democratic nor authoritarian but a mixture of the two types. Larry Diamond (2002) claimed that even in the 1960s and 1970s there existed multiparty, electoral systems that were undemocratic, such as Singapore, Mexico, Malaysia, Senegal, South Africa, Rhodesia and Taiwan (Diamond, 2002: 23). Yet, he proposed a typology that divides democracies into 'electoral democracy' (in the minimalist, Schumpeterian terms) and 'liberal democracy' (Diamond, 2002: 25), and a typology that divides nondemocratic regimes with multiparty electoral competition into 'electoral authoritarian', 'pseudodemocratic,' or 'hybrid' regimes (Diamond, 2002). Levitsky and Way (2010), however, contend that regimes characterized by the minimally democratic element of electoral competition, but lack a reasonably level playing field between the incumbents and opposition fall in the authoritarian rather than the democratic spectrum. The incumbents' abuse of state institutions inevitably leads to the violation of the fairness of the electoral process, which in turn affects several other criteria that are necessary

\footnotetext{
${ }^{2}$ The conflict ended with a redefinition of the Macedonian constitution through the Ohrid Framework Agreement, enhancing the statehood and position of Albanians in Macedonia and introducing a special kind of power-sharing/consociational model.
} 
for a country to be considered a democracy, such as free elections, protection of civil liberties, and a reasonably level playing field (Levitsky and Way, 2010: 7).

Thus, autocratization is characterized by a process whereby the polity had previously established and sustained at least the basic standards of democracy and where the reasonably level playing field between the incumbents and the opposition did exist, but at one point these standards began deteriorating and the polity either downgraded its democracy or slipped into an authoritarian model of governance.

\subsection{Incomplete Democratic Consolidation and Slippage into Competitive Authoritarianism}

For analytical clarity I will use Guillermo O'Donnell's (1994) concepts of first and second democratic transition in order to establish that a country democratized, sustained and started consolidating democracy, and subsequently regressed. Such a distinction is critical, because an analysis based on a premise of a failed democratization may yield erroneous identification of the sources of an existing authoritarian rule.

According to O'Donnell, the establishment of a democratic government does not necessarily lead to a democratic consolidation, such that democracy, as in Alfred Stepan and Juan Linz's (2001) terms, becomes 'the only game in town' (Stepan and Linz, 2001: 94). The first democratic transition from an authoritarian regime only opens the way for a much more complex and longer 'second transition'. The second transition occurs when a democratically elected government becomes an institutionalized and consolidated democratic regime. O'Donnell asserts, however, that there is no guarantee that new democracies would complete a second transition or that they would not possibly regress to authoritarianism. A democratic government becomes consolidated when a set of democratic institutions become the focal points of decision-making processes. Furthermore, policies and strategies of various government agents 'must embody the recognition of a paramount shared interest in democratic institution building' (O’Donnell, 1994: 53). In other words, second transition obtains when broad political elites and populations have internalized the notion of resolution of problems by democratic means. Societies where democratic governance has become robust and institutionalized are able to provide a crucial level of mediation and aggregation between structural factors, individuals and the diverse groupings under which society organizes its multiple interests and identities (O’Donell, 1994: 59). Such institutionalized democratic governance serves as a channel of mediation and articulation of interests. Both formal political institutions and intermediary institutions are part of such an institutional structure that enables social actors to articulate, debate, deliberate or negotiate with each other. The solidification of majority and minority social and political boundaries in Macedonia disrupted the completion of this process; however, this disruption is not necessarily a result of the post 2001 institutional change formalizing power-sharing institutions, but rather the way these institutions have been used.

In contrast, a situation whereby a democratic government has sustained at least basic democratic standards for several consecutive elections after the first transition, and has entered but has not managed to complete the process of the 
second transition will be here called an incomplete democratic consolidation. Countries characterized by an incomplete democratic consolidation, such as Macedonia in the 1990s and early 2000s, exhibit democratic albeit wobbly governance; the democratic institutions are mostly able to manage political conflict, but in political deadlocks sometimes foreign mediation is sought; independent judiciary and other checks and balances do exist but can sometimes be susceptible to political or business pressures; and, more importantly, an influential segment of political leaders and elites have not fully embodied the assumed shared interest in democratic institution building. Additionally, some of the political elites perceive the democratic institutions as a nuisance and as a necessary evil. If an opportunity arises, such political elites circumvent democratic procedures or attempt to influence the independent branches of government, such as the judiciary. In short, countries with an incomplete democratic consolidation, such as Macedonia, are, to an extent, able to provide a level of mediation and aggregation between structural factors and diverse groupings, but the essential institutional checks and balances are not fully immune from partisan influences.

When autocratization occurs in democratized societies, formal democratic institutions mostly remain in place, but the line between the ruling party and the state becomes blurred. As a result, the level playing field between the incumbents and the opposition is disrupted and when this disruption is sustained, competitive authoritarianism ensues (Levitsky and Way, 2002). In competitive authoritarianisms the opposition faces immense impediments in the process of political competition and its likelihood to acquire similar social or economic resources is very low, rendering meaningful competition unlikely. Notwithstanding, Levitsky and Way (2002) point out that although competitive authoritarianisms fall short of democracy, they also fall short of full-blown authoritarianisms. This is so because although incumbents in such regimes may manipulate formal democratic rules, they are unable to completely eliminate them (Levitsky and Way, 2002: 53). Because of the persistence of formal democratic institutions, the opposition in these regimes can still pose challenges to the autocratic incumbents (Levitsky and Way, 2002: 54). These regimes also differ from the regimes where electoral institutions exist but yield no meaningful contestation for power $^{3}$, which according to Levitsky and Way should be classified as full-scale authoritarianisms (Levitsky and Way, 2002).

Macedonia, after its independence from Yugoslavia, with its several democratically elected governments transitioned steadily to democracy throughout the 1990 s, but was unable to complete the second transition. It managed to navigate Macedonian-Albanian inter-ethnic tensions against a highly volatile backdrop - it was impaired by a series of exogenous shocks that triggered major events of ethnic mobilization domestically, such as wars in the neighborhood, conflicts over Kosovo's status, Greek trade embargos and its obstructions to Macedonia's international recognition and legitimacy, all accompanied by a serious economic downgrade. These developments, however, did not systematically compromise democratic processes in that volatile period, and did not require robust international mediation on internal affairs. Although a number of ethnic Albanian grievances persisted - such as equitable

${ }^{3}$ Such as Egypt, Singapore, and Uzbekistan in the 1990s. 
representation of Albanians in state institutions and civil services, and the right to higher education in their mother tongue - political elites continued working on such issues through institutional democratic mechanisms, despite highly divisive conditions. Macedonia's political leaders can largely be credited for this outcome, as despite deep divisions and rifts, they resorted to compromise instead of hardline policies.

\section{Challenges for Completing the Second Transition, Conflict and Collapsing Social Contract}

\subsection{The Military Conflict of 2001}

In April 2001, Macedonia became the second republic of former Yugoslavia (after Slovenia) ${ }^{4}$ to sign the Association and Stabilization Agreement with the European Union as a first step to accession. ${ }^{5}$ This event was expected to pave Macedonia's way to full democratic consolidation and EU membership. However, in February-March that year democratic stabilization and consolidation was suddenly disrupted with a violent conflict, which also marked the beginning of solidification of the inter-ethnic tensions in the country.

In February 2001, Macedonia and FR Yugoslavia signed a treaty on the demarcation of the international border between the two countries (including the border with Kosovo), supported by the international community (Bideleux and Jeffries, 2007: 426). The agreement tightened border control through more frequent patrols, sparkling clashes between Macedonian patrols and ethnic Albanian smugglers from Kosovo (Bideleux and Jeffries, 2007). At the same time, Kosovar-Albanian guerrillas from the Kosovo Liberation Army (UÇK) captured the village of Tanuševci on the Macedonian side of the border, which marked the beginning of the inter-ethnic conflict in Macedonia. A new Albanian paramilitary was created bearing the same acronym as the UÇK in Kosovo, with the meaning 'the National Liberation Army.' At the early stages of the conflict, the international community (NATO, EU and the US) called the insurgents thugs and terrorists and voiced full support for their military defeat by the Macedonian democratically elected government ('Macedonia on a Brink...' 2001; see: Bideleux and Jeffries, 2007: 428). However, the intensified conflict in the following months and spread into wider north-western territories in Macedonia, and at one point in June 2001 combat action reached the outskirts of the capital city of Skopje. The rhetoric of the international community changed meanwhile, urging Macedonian and Albanian political leaders to commence negotiations on constitutional changes and to offer amnesty to UÇK insurgents (Bideleux and Jeffries, 2007: 434).

The protracted conflict disrupted the democratic process and consolidation. A state of emergency was never declared; however, in May 2001 President Trajkovski visited Washington to obtain support for a grand coalition in Macedonia uniting all

\footnotetext{
${ }^{4}$ Slovenia signed an Association Agreement with the EU in 1996.

Council of the European Union (2001) Stabilisation and Association Agreement Between the European Communities and Their Member States, of the One Part, and the Former Yugoslav Republic of Macedonia, of the Other Part. 26 March, Brussels. Available at: http://bit.lv/1HhCmFe Accessed: 18-032015
} 
major parties, winning support from President George Bush for the government's strategy to resolve the conflict through dialogue and through addressing grievances (Bideleux and Jeffries, 2007: 431). The Social Democrats agreed to join the government, thus the ruling coalition expanded to 96 out of 120 members of parliament, and a grand government coalition was formed, comprising the two large ethnic Macedonian parties, VMRO-DPMNE and the Social Democratic Union of Macedonia, as well as the two largest ethnic Albanian parties, the Party for Democratic Prosperity (PDP) and the Democratic Party of Albanians (DPA) (Bideleux and Jeffries, 2007: 432). President Trajkovski's efforts were in line with his compromise-driven policies in an attempt to avert a looming all-out civil war.

\subsection{Culmination of Conflict}

The military conflict intensified in May and June 2001, and in some instances heavy artillery was used. The turning point in the conflict occurred when the UÇK took control of Aračinovo (a village at the capital's periphery with an Albanian majority) in early June, and threatened to shell Skopje, the nearby Skopje Airport and the largest oil refinery in the country (Bideleux and Jeffries, 2007: 435). Such a scenario would bring the country into a full-blown civil war. On June 21, Macedonian police and army forces started an assault on the village using heavy artillery and helicopters. The international community, and particularly NATO, responded to the crisis by arranging a convoy of buses from Kosovo to transport around 350 UÇK fighters and about 200 civilians out of Aračinovo, supplying several trucks to transport UÇK weapons, apparently to another rebel stronghold further to the north (Naegele, 2001).

This event additionally deepened Macedonian-Albanian divisions, since many Macedonians saw NATO's involvement in Aračinovo as taking a side in the conflict and tipping the scale in favour of the Albanians (Petroska-Beska, 2001). Soon after the UÇK fighters were evacuated, news spread that NATO had 'saved the terrorists,' and thousands of angry Macedonians, including hundreds of armed reservists, protested in front of the Parliament and then stormed the building demanding President Trajkovski's resignation, which was a point when anti-Western sentiments among ethnic Macedonians reached their height (Jovanovski, 2001). Many assumed radical elements from within the VMRO-DPMNE were behind the protest, presumably incited by Interior Minister Ljube Boškoski (Jovanovski, 2001), who later stated for the media that the evacuation of Aračinovo had been arranged 'under pressure from the [international community after] every other house waved a white flag' (Naegele, 2001). This event solidified perceptions among many ethnic Macedonians that NATO and the international community were now treating both the Macedonian government and the 'terrorists' as two sides in a conflict. Moreover, many ethnic Macedonians saw threats of aid restrictions from the international community as threats detrimental to the interests of ethnic Macedonians and favorable to ethnic Albanians (Petroska-Beska, 2001). 


\subsection{The Ohrid Framework Agreement: Constitutional Changes and Formalized Power-Sharing}

Fighting decreased in July 2001, and the realization that violence did not really achieve much had started to take root on both sides (Jovanovski, 2001). Negotiations continued between the Macedonians and the Albanians represented by their political parties under the auspices of President Trajkovski and with the involvement of facilitators from the US and EU. The Ohrid Framework Agreement (OFA) was negotiated over seven gruelling weeks and signed in the city of Ohrid on 13 August 2001 by representatives of Macedonia's four main political parties. ${ }^{6}$ The Agreement ended the military conflict and its stipulations became constitutional amendments adopted in Parliament in November 2001 (Dimiskova, 2001). The 15 new amendments modified several important articles of the Constitution defining the nature of the state, including the Preamble, where symbolically Macedonians, Albanians, Turks, Roma, Bosniaks, and Vlachs received a more equal recognition, defined as peoples of Macedonia. Albanian was introduced as the second official language in defined circumstances, and Albanians were guaranteed equitable representation in civil services. Among important constitutional changes was the power-sharing (consociational) provision in Parliament, where the ethnic minority of over 20 per cent of the country's population (namely the Albanians) received an effective veto right to be applied to a range of laws including the new constitutional provisions for the use of symbols and new provisions for local government. These rights were an extension to already existing linguistic, educational and cultural rights from the 1991 Constitution.

Although the Ohrid Framework Agreement addressed many of the grievances of the Albanian ethnic community in Macedonia, the violent conflict of 2001 appears to have been the single most intense formative event solidifying the interethnic conflict. Many ethnic Macedonians had suspicions about the long-term viability of the state with its new constitutional design. They saw the Agreement as a consequence of their perceived military defeat and it having been imposed by outside factors (Gromes, 2009). Macedonians harbored even deeper suspicions about secessionist intentions of their fellow ethnic Albanian citizens. This resentment did not seem to diminish over time, as seven years later 70 per cent of the ethnic Albanians believed that the Agreement provided a good long-term solution for Macedonia, while only 30 per cent of Macedonians agreed. ${ }^{8}$ Such a development illustrates that a second democratic transition would be increasingly cumbersome. That is to say, a large portion of the population, along with influential elites mostly from the right wing spectrum, had

\footnotetext{
${ }^{6}$ International Crisis Group (2001) Macedonia: Filling the Security Vacuum. Balkans Briefing. SkopjeBrussels, 8 September.

Official Gazette of the Republic of Macedonia Constitution of Macedonia with the Amendments to the Constitution I, II, III, IV, V, VI, VII, VIII, IX, X, XI, XII, XIII, XIV, XV, XVI, XVII, XVIII, XIX, XX, XXI, XXII, XXIII, XXIV, XXV, XXVI, XXVII, XXVIII, XXIX and XXX. No. 52/1991; No. 1/1992; No. 4/1992; No. 31/1998; No. 91/2001; No. 84/2003; No. 107/2005 Available at: http://bit.ly/1N8eR2S

${ }^{8}$ Gallup Balkan Monitor (2008) Insights and Perceptions: Voices of the Balkans, 2008 Summary of Findings. Gallup, Inc.
} 
profoundly different understandings and concepts about the paramount shared interest in democratic institution building.

\section{Attempts for Post-Conflict Democratic Consolidation}

\subsection{Decentralization and $\boldsymbol{E} \boldsymbol{U}$ Candidacy Status}

Following the signing of the Ohrid Agreement in September 2002, the Social Democrats won an overwhelming victory, expressly punishing the previous VMRODPMNE nationalist government for its failure to manage the military conflict. The new Albanian Democratic Union of Integration (DUI), which emerged after the conflict, led by former guerrilla leader Ali Ahmeti won 16 seats and became the largest ethnic Albanian party, while the rival DPA won seven. This emerging ethnic Albanian party that immediately became a dominant force among ethnic Albanians was perceived by many Macedonians as a party led by amnestied terrorists. Observer missions characterized the elections as 'an outstanding improvement in the process and implementation of a democratically based electoral system', and 'found no evidence of widespread or systematic irregularity in the balloting process in the six electoral units within Macedonia'. ${ }^{9}$ The Social Democrats and Branko Crvenkovski as a returning Prime Minister formed the new government, inviting the DUI as a junior partner, to the dismay of many Macedonians, since Crvenkovski had earlier promised not to invite former guerrillas into government if his party won the elections (Eftoski, 2002). Such a choice, however, was a result of a tacit acceptance of the power-sharing underlying logic - to share the executive with a winning Albanian ethnic party in order to achieve overall stability and government legitimacy.

The new coalition took on the difficult task of implementing the Ohrid Framework Agreement, consolidating institutions and also to bring the democratic process back on its path to consolidation. Government priority was focused on equitable representation, language and education. The adoption of the OFA package of laws on decentralization still remained to be fulfilled (Marko, 2004). The drafting of the bill on decentralization increased the stakes between the coalition partners, since negotiations focused on gerrymandering in ethnically mixed areas, some of which had experienced a military conflict just a few years earlier. The junior Albanian partner insisted on creating a number of municipalities where Albanians would become new majorities in Western Macedonia. The capital Skopje's boundaries were also changed so that Albanians would constitute over 20 per cent of the population and Albanian would be the second official language in the capital (Marko, 2006). Such gerrymandering was seen by many Macedonians as an attempt to create an ethnically Albanian compact territory in western Macedonia that could potentially become a federal unit. The ruling SDSM, although willing to finalize the OFA implementation with a new decentralization law, only reluctantly accepted such redrawing due to its high unpopularity among a large portion of Macedonians (Gromes, 2009). The

\footnotetext{
${ }^{9}$ International Republican Institute (2002) Republic of Macedonia Parliamentary Election. Election Observation Mission: Report and Recommendations, September 15. Available at: http://bit.ly/1ETtbIJ Accessed: 21-03-2015
} 
opposition VMRO-DPMNE immediately disapproved of the bill and insisted that this plan would increase ethnic tensions. The ruling coalition's parliamentary majority, however, passed the law on 11 August 2004 (Marko, 2004). A Macedonian diaspora organization, the World Macedonian Congress, had already started to collect signatures for a referendum against the new law, and after the bill became law VMRODPMNE stepped in and helped to collect 180,000 signatures ${ }^{10}(150,000$ are required to trigger a referendum) (Marko, 2006).

The referendum campaign began to deepen the rift within the majority Macedonians. Although only 27 per cent of the registered voters turned out (out of the mandatory 50 per cent plus one), resulting in the referendum's failure, over 90 per cent rejected the Decentralization Law. Rumors started to spread that one of the reasons for the referendum's failure was the USA's recognition of the Macedonian constitutional name a day before voting. With the name recognition the US administration purportedly wanted to mollify Macedonian nationalism and encourage Macedonians to reject the referendum by seemingly supporting the Macedonian position in their conflict with Greece over the country's name (Kim, 2005). Although many Macedonians were elated by the US recognition, many others were suspicious and continued to believe that the country was headed to federalization and eventually dissolution (Peshkopia, 2015). Earlier that year, the Macedonian government submitted its application to join the European Union (Beatty, 2004). In December 2005, Macedonia was granted candidate status, mainly as a result of the government's implementation of the OFA and its post-conflict consolidation (Krasniqi, 2005). The European Union had hoped that this status would boost Macedonia's democratic consolidation during preparation for full membership.

\subsection{Elections in 2006 and the Greek Veto for NATO Membership}

The EU candidate status, however, was not sufficient for keeping the incumbent SDSM-DUI coalition in power. VMRO-DPMNE under the leadership of its young leader Nikola Gruevski largely consolidated from its perceived success in mobilizing ethnic Macedonians in 2004 against the decentralization law, as well as its relative success in the 2005 local elections. ${ }^{11}$ Gruevski presented himself as a reformer and a moderate conservative who ran on a platform of 'economic and national rebirth (Karajkov, 2006),' winning the general election with 45 (out of 120) seats in Parliament. Within the Albanian camp the DUI won 17 and the DPA 11 seats. ${ }^{12}$ Albeit with some instances of violence, the elections were characterized as free and fair, fulfilling international standards (Røseth, 2006). VMRO-DPMNE invited the DPA as a junior partner, along with other smaller partners, such as the New Social Democratic party, which had earlier split from the Social Democratic Union of Macedonia. The VMRO-DPMNE and DPA coalition was a breach of the established, albeit informal, norm that the Albanian ethnic party with the largest support among

\footnotetext{
${ }^{10} 150,000$ are required to trigger a referendum.

${ }^{11}$ Macedonia Local Elections: Election Summary (2005) Southeast European Times, 13 March. Available at: http://bit.ly/1DZmaZm Accessed: 20-03-2015

${ }^{12}$ Election Guide (2006). Macedonia, 5 July. Available at: http://www.electionguide.org/elections/id/1452/ Accessed: 15-03-2015
} 
Albanians would be part of the executive. Such a breach signaled VMRO-DPMNE's disregard of the power-sharing arrangement spirit. DUI had insisted it should be part of the executive since it represented the will of the majority of the Albanians (Karajkov, 2006). Such an informal breach further hindered the full democratic consolidation as the DUI considered the government illegitimate (Karajkov, 2006).

The critical juncture, however, occurred at the Bucharest NATO Summit in 2008. Macedonia, along with Albania and Croatia, had been preparing within the NATO Action Plan for full membership; however, Greece vetoed its membership on grounds of the unresolved name dispute (Peshkopia, 2015: 199). This event started a spiral of protracted intra-Macedonian rifts, along with the solidified MacedonianAlbanian divisions. NATO and EU membership had been a national consensus, but the name of the country has been particularly important to the majority population (ethnic Macedonians), considering that a change of the country's name for many Macedonians meant an alteration of the country's identity and, along with its new constitutional design, further deterioration of its capacities for survival and cultural reproduction. Moreover, in strategic terms, Macedonia's NATO membership (and later EU membership) had been the overwhelming consensus among Macedonian and Albanian political factors across the spectrum. The Euro-Atlantic integration, especially for Macedonians, had been seen as the utmost strategic goal in that it would effectively level the playing field between Macedonia and Greece in the resolution of the name dispute later on, while for Albanians this meant security and open borders with their kin in Albania and Kosovo once they integrated, too. At the same time, most ethnic Albanians did not find the country's name of paramount significance; they believed the country's integration into the Euro-Atlantic structures to be more important than whatever the name compromise would be (Peshkopia, 2015: 197; Gromes, 2009: 26). The Greek veto in 2008 deepened the intra-Macedonian rift revolving around the rhetoric of traitors and defenders of national interests, which will be tackled in more detail in the following section. The prior solidification of the interethnic division and the newly formed intra-Macedonian divisions that exceeded the boundaries of political contestations and entered the sphere of identitarian divisions, marked Macedonia's profound challenge to complete the second transition and fully consolidate democratically, since both the inter-ethnic and intra-ethnic social contracts had been gradually collapsing.

\section{Primordialization of Nationalism and Autocratization}

Macedonia's primordialization of nationalism and autocratization were set in motion after the Greek veto in NATO, when Prime Minister Gruevski called for early elections in June 2008. Unlike in 2006, he ran on a highly nationalistic platform capitalizing on the Macedonians' frustration with the Greek veto earlier that year. $\mathrm{He}$ accused the Social Democrats of choosing to sell off the country's name for NATO membership. Gruevski exclaimed that he wanted a triumph, and not just a victory, which he got by winning 63 out of 120 seats in Parliament, the greatest win in the history of the party, while the Social Democrats only won 27 (Auer, 2008). The DUI won 18 seats, confirming its leading position among the Albanians while the DPA garnered 11. Despite VMRO-DPMNE's convincing victory, international observers 
called the 2008 election the worst in Macedonia's history as an independent state, due to widespread violence before and on the day of the election, mostly within the Albanian ethnic community (Auer, 2008; OSCE, 2008). ${ }^{13}$ Since the DPA had left the coalition with VMRO-DPMNE and decided to be an opposition force before the elections, Gruevski had to invite the DUI as its junior coalition partner. Moreover, DUI was able to secure the double parliamentary majority, a constitutional device requiring a majority of votes from the ethnic minority representatives on a range of legislations. Later in 2008, Greece also blocked the beginning of Macedonia's EU accession negotiations, marking a potential long-term stalling of Macedonia's EuroAtlantic integrations. ${ }^{14}$

Pandering to heightened majority Macedonian nationalism resulting from the Greek vetoes in 2008, Gruevski's government initiated a large-scale reconstruction of the capital city of Skopje in neoclassical and baroque styles in 2010, naming it the Skopje 2014 project. The project featured an eight-story-tall statue of Alexander the Great towering over Macedonia Square (Graan, 2013: 161). This statue was erected as the cornerstone of a larger government strategy to 'strengthen' the Macedonian nation, generating notable discontent and polarization in Macedonian society (Graan, 2013: 162). This project was Gruevski's apparent answer to Greece's vetoes on Macedonia's Euro-Atlantic integrations, ${ }^{15}$ by introducing a 'national renaissance' project termed by its opponents an antiquization of the Macedonian identity (Vangeli, 2011). The antiquization meant a primordialized view of the Macedonian ethnic identity with its roots in the ancient kingdom of Macedonia. This primordialized narrative was to assert Macedonia's name, identity and history domestically and internationally amid Greek challenges and blockages of Macedonia's international legitimacy. On one side, the project's many supporters celebrated the makeover, while opponents of the plan ${ }^{16}$ on the other side offered arguments that its mono-ethnic primordialized narrative of Macedonian history would exacerbate ethnic tensions: that its flaunting of Macedonian claims to antiquity would unnecessarily antagonize neighboring Greece; that the implementation of this project bypassed proper public consultation and incurred enormous costs in one of the poorest countries in Europe (Graan, 2013: 162). The project not only turned into another bone of contention between Macedonians and Albanians, but it also triggered a deep intra-Macedonian rift over the Macedonians' identity. Ethnic Macedonians divided into two camps, popularly dubbed 'Ancient' and 'Slavic,' which, as a division tended to replicate itself through political mobilization (Vangeli, 2011: 24). Also, Gruevski's government, with the use of co-opted media, launched a campaign labelling anyone opposing the project a traitor of national interests, a "Sorosoid"17 and a Greek mercenary (Brunwasser,

\footnotetext{
${ }^{13}$ Freedom House (2009) Macedonia Country Report. Available at: http://bit.ly/29RdblI Accessed: 12-03$\underline{2015}$

${ }^{14}$ International Crisis Group (2009) Macedonia's Name: Breaking the Deadlock. Europe Briefing No. 52. Pristina-Brussels, 12 January.

${ }^{15}$ The ultimate Greek intent with its vetoes on Macedonia's Euro-Atlantic integrations was to force the country to change its constitutional name.

${ }^{16}$ Students, architects, intellectuals, members of Macedonia's NGO sector.

${ }^{17}$ 'Sorosoid' is a derogatory term coined to designate NGOs and activists purportedly supported by the Soros-Open Society Institute in Macedonia.
} 
2011). ${ }^{18}$ The Albanian parties have expressed concerns that this nationalist strategy was alienating Macedonia's friends in the EU (Brunwasser, 2011). Albanian leaders have also underlined that the nationalist policies have undermined the foundation of post 2001 Macedonian society and its inclusive model of representation (Vangeli, 2011: 24). Earlier in 2009, Prime Minister Gruevski had issued a public letter to all his supporters calling for a final battle with 'Macedonia's traitors,' 'to cut and prevent their attempts to take our country and citizens hostage again'. ${ }^{19}$ The project and the rhetoric of defenders vs. traitors brought the relentless intra-Macedonian rift to new levels, since the attempt to infuse a new feeling of Macedonian ethnic identification with ancient roots and lineage does not entirely resemble the nation building strategies employed elsewhere on the constitution of new nation-states throughout the $19^{\text {th }}$ and $20^{\text {th }}$ centuries. Namely, the Macedonian ethnic identification had already been well established after the constitution of the Macedonian republic within Yugoslavia with prevailing national narratives tied to the ancestry of the medieval Slavic culture in Macedonia and the revolutionary struggles for liberation from Ottoman rule in the $19^{\text {th }}$ century.

The incumbent VMRO-DPMNE won the municipal elections in 2009 along with the presidential elections, with Gjorge Ivanov as its candidate. ODIHR reported about credible allegations from all over the country of pressure on or intimidation of citizens, which seriously detracted from the overall quality of the election process. Public-sector employees appeared to be particularly vulnerable to threats that their jobs would be in danger if they did not support the governing party. ${ }^{20}$

In sum, the deterioration of democratic standards became evident following Macedonia's hurdle in NATO and EU integration, when VMRO-DPMNE's government, inter alia, began implementing 'national renaissance' or primordialization policies, fueling majority Macedonian nationalism but also triggering a deep intraMacedonian rift over the Macedonians' identity, thereby not only further solidifying the inter-ethnic divisions in Macedonia, but also creating a new identitarian cleavage within the Macedonians themselves. These policies aimed at reconstructing the country's identity symbolically upon a vision of a Macedonian nation-state with ancient roots. Moreover, these policies enabled Prime Minister Gruevski to assert himself as an authoritarian leader who ignores public debate over divisive policies, cracks down on independent and critical media, and uses the media under his control to stigmatize his opponents as traitors against the national interests.

\subsection{Slippage into Competitive Authoritarianism}

Macedonia's slippage into competitive authoritarianism can be observed along several crucial indicators that illustrate the systematic and systemic disruption of the

\footnotetext{
${ }^{18}$ SDSM i Sorosovite platenici orkestrirano ja napadnaa svojata zemja na Al Jazeera. (SDSM and Soros Mercenaries Orchestrated an Attack on Their Own Country on Al Jazeera) (2015) Puls 24, 19 March Available at: http://bit.lv/19PNhcT Accessed: 21-03-2015

${ }^{19}$ Prime Minister Calls for Last Battle with Macedonia's Traitors (2009) MINA, 18 November 2009. Available at: http://bit.ly/1N8eAgy Accessed: 13-03-2015

${ }_{20}$ Organization for Security and Cooperation in Europe-OSCE (2009) http://www.osce.org/odihr/elections/fyrom/37851?download=true Accessed: 24-03-2015
} 
level playing field between the incumbents and the opposition, such as unfair media access, abuse of state resources and institutions, and harassment of political opponents. Prime Minister Gruevski called yet again for early elections in 2011, allegedly responding to opposition demands. The elections occurred during judicial proceedings against the owner of the most popular private national TV station A1, Velija Ramkovski. Ramkovski had been accused of tax fraud and embezzlement, at a time when A1 TV started to criticize Gruevski's government vigorously. Gruevski and VMRO-DPMNE won the elections with 56 seats, but did not expect the opposition to garner as many as 42 seats in Parliament. ${ }^{21}$ In electoral legislation changes, shortly before the elections were held, three more seats were added for traditionally pronationalistic diaspora representatives. In its 2011 Elections Report, ODIHR expressed concern that altering the legal framework so close to an election was not in line with good electoral practice, as it affected the timely and consistent implementation of the law. Furthermore, ODIHR reiterated that during the campaign there had been instances of an insufficient separation between state and party structures, contrary to paragraph 5.4 of the 1990 OSCE Copenhagen Document. ${ }^{22}$ Such lack of separation included misuse of state resources for campaign purposes and partisan rhetoric when candidates acted in an official capacity, which detracted from the overall quality of the election process. ${ }^{23}$

In the domain of the media, Macedonia ranked $36^{\text {th }}$ on the Press Freedom Index in 2007 ahead of, or in close proximity to, developed and consolidated democracies, such as the United States $\left(48^{\text {th }}\right)$, Italy $\left(35^{\text {th }}\right)$ and Japan $\left(37^{\text {th }}\right)$. Between 2008 and 2014, Macedonia plummeted by a staggering 87 places, to end up at $123^{\text {rd }}$ position, behind The United Arab Emirates (118 $)$ and just slightly ahead of Afghanistan $\left(128^{\text {th}}\right) .{ }^{24}$ In addition, the US Department of State in its 2013 Macedonia Human Rights Report noted that the mainstream media rarely published views opposing the government. The government was the largest purchaser of advertising in the country, making media outlets financially dependent on revenue from the government and therefore subject to pressure not to present views critical of the government. Along with electoral manipulation and control of the media space, VMRO-DPMNE's government has been repeatedly accused of abusing state resources for its political campaigns. Gruevski's government had intimidated judicial institutions over which he had not had full control, such as the Constitutional Court. Political interference, inefficiency, favoritism towards well placed persons, prolonged judicial processes, and corruption characterized the judicial system. ${ }^{25}$

VMRO-DPMNE and Prime Minister Gruevski have been accused of harassing, imprisoning and taking revenge on political opponents on a number of occasions. One such instance was the prosecution of former Interior Minister Ljube

\footnotetext{
${ }^{21}$ World Elections (2011) Macedonia, 6 June. Available at: http://bit.ly/1BM5Nsc Accessed: 23-03-2015 Organization for Security and Cooperation in Europe-OSCE (2011) http://www.osce.org/odihr/elections/83666?download=true Accessed: 24-03-2015 Accessed: 24-03-2015

${ }_{23}$ Organization for Security and Cooperation in Europe-OSCE (2011) http://www.osce.org/odihr/elections/83666?download=true Accessed: 24-03-2015 Accessed: 24-03-2015

${ }_{21}$ Reporters Without Borders (2014) World Press Freedom Index 2014. Available at: http://bit.ly/29RzHVK Accessed: 14-03-2015

${ }_{25}^{25}$ US Department of State (2013) Country Reports on Human Rights Practices for 2011: MacedoniaExecutive Summary. Available at: http://1.usa.gov/1eDodVg Accessed: 12-03-2015
} 
Boškoski, arrested just a day after the general elections in 2011 on charges of illegal election campaign financing and misuse of official position. ${ }^{26}$ Police allowed journalists to film the arrest, including the seizure of 100,000 euros in cash and a gun from Boškoski's vehicle. Harassment, intimidation and detention continued against political opponents in 2013, such as the arrest of Miroslav Šipović, president of the oppositionled Skopje-Centar Municipal Council, on charges of fraud and embezzlement. ${ }^{27}$ Sipović's arrest meant that the opposition coalition could lose its slim majority on the Skopje-Centar Municipal Council, marking a political gain for the ruling coalition. ${ }^{28}$ Skopje-Centar is one of only four opposition-administered municipalities and is the most coveted municipality in Macedonia in terms of political symbolism and revenue. It was the municipality through which most of the Skopje 2014 project had been financially realized. In December 2012, unidentified security personnel forcibly ejected the Macedonian opposition and journalists from Parliament, amid opposition attempts to institutionally block the adoption of the profligate 2013 state budget (Čašule, 2012). ${ }^{29}$ SDSM thereafter boycotted the Parliament, launched protests against the government, and also threatened to boycott the spring 2013 local elections, which precipitated a major political crisis only resolved by EU mediation. ${ }^{30}$

In an effort to further strengthen his rule, Prime Minister Gruevski called early general elections again in April 2014, along with the regular presidential elections, aiming to secure a simple majority for his party so as to avert 'Albanian political blackmails' (Marušić, 2014a). His party won 61 seats (just one short of a simple majority), while the SDSM won 34, the DUI 19 and the DPA seven. ${ }^{31}$ The ODIHR used the strongest criticisms compared to previous reports, stating that biased media coverage and a blurring of state and party activities deprived candidates of a level playing field in contesting the election, contrary to paragraphs 5.4 of the 1990 OSCE Copenhagen Document and Council of Europe standards. ${ }^{32}$ In the wake of voting day the opposition leader Zoran Zaev announced that the SDSM would not accept the election results and accused Gruevski of 'abusing the entire state system'. ${ }^{33}$ Later Zaev announced the SDSM would boycott the Parliament, stating that Macedonia was 'a dictatorship in which the voter and the citizens were being controlled' ${ }^{34}$ The boycott continued throughout 2014, and later in the year university students, professors, NGO

\footnotetext{
${ }^{26}$ US Department of State (2011) Country Reports on Human Rights Practices for 2011: MacedoniaExecutive Summary. Available at: http://1.usa.gov/1CP3cmK Accessed: 12-03-2015

${ }^{27}$ US Department of State (2013) Country Reports on Human Rights Practices for 2011: MacedoniaExecutive Summary. Available at: http://1.usa.gov/1eDodVg Accessed: 12-03-2015

${ }^{28}$ US Department of State (2013) Country Reports on Human Rights Practices for 2011: MacedoniaExecutive Summary. Available at: http://1.usa.gov/1eDodVg Accessed: 12-03-2015

${ }^{20}$ US Department of State (2013) Country Reports on Human Rights Practices for 2011: MacedoniaExecutive Summary. Available at: http://1.usa.gov/1eDodVg Accessed: 12-03-2015

${ }^{30}$ World Elections (2014) Macedonia, 1 May. Available at: http://bit.ly/1Iv4XGa Accessed: 23-03-2015

${ }^{31}$ World Elections (2014) Macedonia, 1 May. Available at: http://bit.ly/1Iv4XGa Accessed: 23-03-2015 Organization for Security and Cooperation in Europe-OSCE (2014) http://www.osce.org/odihr/elections/117636?download=true Accessed: 24-03-2015

${ }_{33}$ Macedonia Opposition Rejects Election Results (2014) Al Jazeera, 27 April 2014. Available at: http://bit.ly/1Bn00KI Accessed: 18-03-2015

${ }^{34}$ Macedonian Opposition Boycotts Parliament Over Claims of Election Fraud (2014) EurActiv, May 19. Available at: http://bit.lv/1v6Jv3Y Accessed: 12-03-2015
} 
members and members of other civil associations took to the streets to protest against laws largely seen as undemocratic and anti-constitutional. In a series of protests, thousands of students marched against the bill on higher education. Students claimed that the envisaged state, 'external,' exams would hinder freedom of education and abolish university autonomy (Marušić, 2014b). Many professors, human rights activists and student movements from other countries lent their support to the students. Moreover, signaling potential for cross-ethnic resistance to authoritarian government, Albanian students in Macedonia also joined the rallies, which was likely the first such mass rally since independence where both Macedonians and Albanians marched together.

The overarching abuse of state institutions by Prime Minister Gruevski and his VMRO-DPMNE party and the embedded competitive authoritarian nature of the regime was further exposed by a mega wiretapping scandal. In February and March 2015, opposition leader Zoran Zaev accused Prime Minister Gruevski and his counter-intelligence chief, Sašo Mijalkov (Gruevski’s first cousin), of orchestrating illegal surveillance of more than 20,000 people for at least four years, including close collaborators and government ministers (Čašule, 2015). Prime Minister Gruevski, precipitating Zaev's public address, announced that Zaev had been charged with conspiring with a foreign intelligence service to topple the government (Čašule, 2015). Zaev began revealing tapped phone conversations of the highest officials, popularly dubbed political bombshells, including conversations between Gruevski himself and his closest collaborators in government, such as Interior Minister Gordana Jankulovska, the Minister of Finance Zoran Stavrevski, and other ministers, members of parliament and party members. The conversations reveal alleged wide abuse of public office, large-scale graft committed by upper-ranked government officials, framing political opponents for arrest, financial crime, a take-over of the public prosecutor's office and the courts (including the Supreme Court), and other systematic misdeeds. The conversations reveal far-reaching and deeply entrenched cronyist and clientelist relationships among politicians, entrepreneurs and social actors in all echelons of society. Some of the revealed materials suggest that the Albanian junior coalition partner in government has also been incorporated in such deeply entrenched clientelism and cronyism. Also, the materials suggest that coalition partner relations have been built primarily upon corruptive dealings, as seen in the regular trade-offs for positions in state institutions (including the judiciary) of loyal party members. The authenticity of the recordings was never clearly contested; however, Gruevski, although reluctant to comment on the contents, stated that the tapped conversations had been concocted by an unnamed foreign secret service (Marušić, 2015). The EU characterized the crisis as 'very worrying', adding to concerns that the political glue that held the country's ethnic-Macedonian and ethnic-Albanian communities together was becoming weaker ${ }^{35}$. The EU official remarked that the weaker that glue became, the greater the chance of ethnic conflict (Gardner, 2015). Zoran Zaev and the SDSM, including other smaller political parties, civil organizations and citizens demanded the immediate resignation of Gruevski's government and an

${ }^{35}$ The glue being the prospect of joining EU and NATO. 
establishment of a transitory caretaker government, which would then organize free and fair elections.

In sum, since at least 2011, Macedonia has slipped into a competitive authoritarian manner of governance and Gruevski's regime has been consolidating a deeply entrenched clientelistic regime, widely abusing public office, fusing his family, friends and closest party members with the judiciary, prosecutors' offices and other state bodies that are otherwise necessary to ensure the system of horizontal accountability in a democratic system (O'Donnell, 1998). Such fusion and wide political abuse, along with an almost absolute control of influential broadcast and print media, has severely, systematically and systemically disrupted the reasonably level playing field for political competition between the incumbents and the opposition. The Albanian junior coalition partner has been co-opted within the system of clientelism and cronyism. It appears that such a relationship has temporarily frozen the already solidified interethnic conflict in that both coalition partners have a common interest to support each other in maintaining power.

\section{Conclusion}

Nationalist conflict has been one of the most salient sources of Macedonia's democratic instability, its inability to achieve full democratic consolidation and its subsequent autocratization. After the first transition in 1990 Macedonia survived as a democratic country; however, it did not manage to finalize its second transition. The outcomes from the Kosovo crisis in 1999 and the ensuing security challenges contributed to the Macedonian-Albanian military conflict in 2001. This development triggered the process of solidification of the inter-ethnic conflict. The implementation of constitutional reforms from 2002-2006 marked the attempt for a democratic consolidation, a period when Macedonia became an EU candidate. However, the intra-Macedonian and Macedonian-Albanian disputes over the process of decentralization with its securitization and ethnicization, further exacerbated Macedonian-Albanian nationalist tensions in that majority Macedonians perceived the constitutional changes as a national defeat and reluctantly accepted the outcomes, while Albanians embraced the constitutional reforms and saw them as an overall victory in their struggles. Such solidification, thus, strongly influenced the ensuing rise and reaffirmation of Macedonian nationalism through its attempt to reject the decentralization law, which consolidated the Macedonian nationalist opposition and helped it return to power in 2006. Greece's veto on Macedonia's NATO membership singlehandedly deepened the intra-Macedonian rift, transforming Macedonian ethnic nationalism into an identitarian intra-ethnic conflict revolving around the rhetoric of traitors and defenders of the Macedonian ethno-nation. The protracted MacedonianAlbanian inter-ethnic contestations and the growing intra-Macedonian rifts marked Macedonia's profound challenge to complete the second transition and fully consolidate democratically. The transformed political and nationalist landscape marked the beginning of autocratization, through the government's implementation of 'nation-renaissance' policies of primordialized nationalism. These policies sealed the inter-ethnic divisions in Macedonia as they attempted to construct the country's identity upon a vision of a Macedonian nation-state with its roots in ancient 
Macedonia. Simultaneously, such primordialization policies engendered a deeper rift within the Macedonian majority by creating a new identitarian cleavage, in which the two camps subscribed to different and opposing narratives regarding their national identity. At the same time, these policies and the ensuing nationalist mobilization emboldened Prime Minister Gruevski to assert himself as an authoritarian leader ignoring public debate, cracking down on independent and critical media, stigmatizing and delegitimizing his opponents as traitors against national interests, and prosecuting political opponents, journalists and members of the civil society. Macedonia slipped into competitive authoritarian rule after the elections of 2011 and competitive authoritarianism was especially buttressed after the purge of the opposition from Parliament in 2012, when Gruevski's regime firmly embarked on creating and later consolidating a deeply entrenched clientelistic and cronyist regime, widely abusing public office, clientilizing the judiciary, the public prosecution and other essential checks and balances.

The implications of this case study can be manifold. First, it illustrates the importance of distinguishing between failed democratization and incomplete democratic consolidation in democratizing societies, which allows for a more precise identification of the nature of ongoing processes and problems with governance. Second, this case suggests that the broad semi-consociational institutionalization of ethnic minority rights might not necessarily consolidate democratic institutions, since they could be consensually hijacked by political elites and used for establishing entrenched cronyism and clientelism. The ethno-nationalist conflict can become institutionally trapped and reproduce itself before every electoral round, which can then systemically impede democratic governance and make the society more susceptible to authoritarianism. The patterns of autocratization that of late seem palpable in other previously democratized countries of Central and Eastern Europe, where authoritarian tendencies along with the rise of right wing politics have been observed in countries like Hungary, and more recently in Poland and Serbia, seem strikingly similar to the case analyzed in this study. Also, the case can be illustrative of how exclusive and primordialist nationalism can systematically impede democratic processes and endanger democracy itself in the context of the broader European political crisis with the rise of right wing and nationalistic politics and policies. Lastly, this study can also serve as basis for investigation into how politically contingent 'national renaissance' policies can take deeper social roots within a relatively short period and how they can be used for nationalist mobilization as a means of consolidating authoritarian rule.

\section{References}

Abazi, V. (2014) Macedonia: Illiberal Democracy. CEPS Commentary. Brussels: Centre for European Policy Studies.

Auer, D. (2008) Elections Expose Centrifugal Forces at Work in Macedonia. World Politics Review, WPR Briefing. 23 June. Available at: http://bit.ly/1N8dcKX Accessed: 19-03-2015 
Beatty, A. (2004) Macedonians to Submit Delayed EU Application. EU Observer, 22 March. Available at: https://euobserver.com/enlargement/14877 Accessed: 1803-2015

Beissinger, M. (2002) Nationalist Mobilization and the Collapse of the Soviet State. Cambridge: Cambridge University Press. DOI: https://doi.org/10.1017/cbo9780511613593

Bermeo, N. (2003) Ordinary People in Extraordinary Times: The Citizenry and the Breakdown of Democracy. Princeton, Oxford: Princeton University Press.

Bideleux, R. and Jeffries, I. (2006) The Balkans: A Post-Communist History. New York: Routledge. DOI: https://doi.org/10.4324/9780203969113

Brubaker, R. (1996) Nationalism Reframed: Nationhood and the National Question in the New Europe. Cambridge: Cambridge University Press. DOI: https://doi.org/10.1017/cbo9780511558764

Brunwasser, M. (2011) Concerns Grow About Authoritarianism in Macedonia. New York Times, 11 October. Available at: http://nyti.ms/18XcaCb Accessed: 1203-2015

Čašule, K. (2015) Macedonian PM Hits Back in Surveillance Scandal. Reuters, 15 March. Available at: http://bit.ly/29LWKS1 Accessed: 16-03-2015

Čašule, K. (2012) Macedonia Opposition Ejected From Parliament in Row. Reuters, 24 December. Available at: http://reut.rs/1BqDmQF Accessed: 17-03-2015

Crenson, A. M. and Ginsberg, B. (2002) Downsizing Democracy: How America Sidelined Its Citizens and Privatized its Public. Baltimore, London: The Johns Hopkins University Press.

Czigler, T. D. (2012) The Anti-Democratic Tendencies Now Prominent in Some Parts of Eastern Europe May Soon Become an Even Bigger Headache for the EU than the Eurozone Crisis. European Politics and Policy, London School of Economics. 30 August. Available at: http://bit.ly/S12zk4 Accessed: 25-07-2016

Daskalovski, Z. (1999) Democratization in Macedonia and Slovenia. Southeast Europe Review, 2(3): 17-44.

Diamond, L. (2002) Thinking about Hybrid Regimes. Journal of Democracy, 13(2): 21-35. DOI: https://doi.org/10.1353/jod.2002.0025

Dimiskova, S. (2001) Ohrid Agreement Cast In Constitutional Form. Dnevnik, 17 November. Available at: http://bit.ly/1Ng701w Accessed: 10-03-2015

Eftoski, G. (2002) Vo vlada na SDSM nema mesto za Ali Ahmeti (In a SDSM led Government No Place for Ali Ahmeti). Utrinski Vesnik, 5 June. Available at: http://star.utrinski.com.mk/PpBroj=884\&stID=11977\&pR=3 Accessed: 14 $03-2015$

Gardner, A. (2015) Wire-Tapping Scandal Hits Macedonia. European Voice, 26 February 2015. Available at: http://bit.ly/18XcCjX Accessed: 15-03-2015 
Graan, A. (2013) Counterfeiting the Nation? Skopje 2014 and the Politics of Nation Branding in Macedonia. Cultural Anthropology, 28(1): 161-179. DOI: https://doi.org/10.1111/j.1548-1360.2012.01179.x

Gromes, T. (2009) Between Impositions and Promises: Democracy in Macedonia. Frankfurt: Peace Research Institute Frankfurt (PRIF).

Gyarfasova, O. (2013) Eastern Europe's Third Decade of Democracy. EurActiv, 18 February 18 2013. Available at: http://bit.ly/1FUXCQl Accessed: 05-03-2015

Jovanovski, V. (2001) On the Brink of Peace. Transitions Online, July 11. Available at: http://bit.ly/1HFfO2t Accessed: 19-03-2015

Karajkov, R. (2006) Macedonia: New Government. Osservatio Balcani e Caucaso, 31 August. Available at: http://bit.ly/1HFfUqR Accessed: 17-03-2005

Kim, J. (2005) Macedonia (FYROM): Post-Conflict Situation and U.S. Policy. CRS Report for Congress, 17 June. Available at: http://bit.ly/1Iv3YWt Accessed: 1703-2015

Krasniqi, E. (2005) Macedonia Granted EU Candidate Status. ISN Zurich, 19 December. Available at: http://bit.ly/1FG82ot Accessed: 20-03-2015

Levitsky, S. and Way, L. A. (2002) The Rise of Competitive Authoritarianism.” Journal of Democracy, 13(2): 51-65. DOI: https://doi.org/10.1353/jod.2002.0026

Levitsky, S., and Way, L. A. (2005) International Linkage and Democratization. Journal of Democracy, 16(3). DOI: https://doi.org/10.1353/jod.2005.0048

Levitsky, S., and Way, L. A. (2010) Competitive Authoritarianism: Hybrid Regimes After the Cold War. Cambridge: Cambridge University Press. DOI: https://doi.org/10.1017/cbo9780511781353

Marko, J. (2004) The Referendum on Decentralization in Macedonia in 2004: A Litmus Test for Macedonia's Interethnic Relations. European Yearbook of Minority Issues, 4: 695-721. DOI: 10.1163/22116117-90000031

Marušić, S. J. (2014a) Macedonia Parties Mobilize Ethnic Supporters. Balkan Insight, 4 March 2014. Available at: http://bit.ly/1BnaY2F Accessed: 18-03-2015

Marušić, S. J. (2014b) Student Protesters Rally Outside Macedonia's Govt HQ. Balkan Insight, 26 December 2014. Available at: http://bit.ly/1Iv48Nq Accessed: 20-03-2015.

Marušić, S. J. (2015) Macedonia MPs Kept on Tight Leash, Tapes Reveal. Balkan Insight, 20 March. Available at: http://bit.ly/2Bu457p Accessed: 21-03-2015

Müller, J. W. (2014) Eastern Europe Goes South: Disappearing Democracy in the EU's Newest Members. Foreign Affairs, April. Available at: http://fam.ag/1hpjoPf Accessed: 13-03-2015 
Naegele, J. (2001) Macedonia: Nation Moves One Step Closer To Anarchy. Radio Free Europe Radio Liberty, 26 June 2001. Available at: http://bit.ly/1btrgRB Accessed: 16-03-2015

O’Donnell, G. (1994) Delegative Democracy. Journal of Democracy, 5(1): 55-69. DOI: https://doi.org/10.1353/jod.1994.0010

O'Donnell, G. (1998) Horizontal Accountability in New Democracies. Journal of Democracy, 9(3): 112-126. DOI: https://doi.org/10.1353/jod.1998.0051

Organization for Security and Cooperation in Europe-OSCE (1998) Parliamentary Elections in the Former Yugoslav Republic of Macedonia: 18 October And 1 November 1998. OSCE/ODIHR Election Observation Mission

Final Report. Warsaw: Office for Democratic Institutions and Human Rights. Accessed: 10-03-2015

Organization for Security and Cooperation in Europe-OSCE (2008) http:/www.osce.org/odihr/elections/fyrom/33153?download=true Accessed: 24-03-2015

Peshkopia, R. (2015) Conditioning Democratization: Institutional Reforms and EU Membership Conditionality in Albania and Macedonia. London: Anthem Press.

Petroska-Beska, V. (2001) Macedonia's Perception Gap. The Christian Science Monitor, $16 \quad$ August $2001 . \quad$ Available at: http://www.csmonitor.com/2001/0816/p9s1-coop.html Accessed: 14-03-2015

Røseth, T. (2006) Former Yugoslav Republic of Macedonia: Parliamentary Elections. NORDEM Report 14. The Norwegian Centre for Human Rights/NORDEM. Available at: http://bit.ly/2ncaHUT Accessed: 10-03-2015

Simon, W. B. (1978) Democracy in the Shadow of Imposed Sovereignty: The First Republic of Austria. In: Linz, J. J. and Stepan, A. (ed.) The Breakdown of Democratic Regimes. Baltimore, London: The Johns Hopkins University Press. 80-122.

Somun, H. (2014) Putinization of Not Only Balkans, but Europe as Well. Center for Geopolitical Analyses, 17 June. Available at: http://bit.ly/2ndC15q Accessed: 27-07-2016

Stepan, A. and Linz, J. J. (eds.) (1978) The Breakdown of Democratic Regimes. Baltimore, London: The Johns Hopkins University Press

Stepan, A. and Linz, J. J. (2001) Toward Consolidated Democracies. In: Diamond, L. and Plattner, M. F. (eds.) The Global Divergance of Democracies. Baltimore, London: Johns Hopkins University Press.

Strzelecki, M. and Skolimovski, P. (2016) Poland Pressed Over Democracy as Report Spurs Demonstrations. Bloomberg, 12 March. Available at: https://bloom.bg/2AaTbFE Accessed: 27-07-2016 
Svolik, M. (2008) Authoritarian Reversals and Democratic Consolidation. The American Political Science Review, 102(2): 153-168. DOI: https://doi.org/10.1017/s0003055408080143

UNHCR (1999) The Former Yugoslav Republic of Macedonia at a Glance. UNHCR Global Report, 1999.

Vangeli, A. (2011) Nation-Building Ancient Macedonian Style: The Origins and the Effects of the So-Called Antiquization in Macedonia. Nationalities Papers, 39(1): 13-32 DOI: https://doi.org/10.1080/00905992.2010.532775

Żornaczuk, T. (2014) Macedonia: From Balkan Leader to Sick Democracy. Bulletin, The Polish Institute of International Affairs, 20 May 2014.

Macedonia on a Brink of Abyss (2001) BBC, 7 May. Available at: http://news.bbc.co.uk/2/hi/europe/1317049.stm Accessed: 13-03-2015 